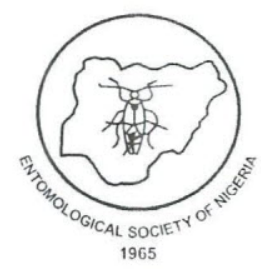

Nigerian Journal of Entomology Published by the Entomological Society of Nigeria

\title{
Impact of Tillage Remediation on Soil Microarthropods and Nutrients in Hydrocarbon Contaminated Soil Ecosystem at Ikarama Community, Bayelsa State, Nigeria
}

\author{
*'GBARAkoro, T. N., ${ }^{2}$ OGEle, E. J. AND '3MEOZOR, O. C. \\ ${ }^{123}$ Department of Animal and Environmental Biology, \\ University of Port Harcourt
}

Nig. J. Entomol. 33: 111-120(2017)

\begin{abstract}
Impact of tillage remediation on soil nutrients and its relationship with soil fauna abundance in hydrocarbon contaminated soil ecosystem was assessed at Ikarama community, Bayelsa State, Nigeria, where Shell Petroleum Company, Nigeria carried out remediation. The assessment which lasted for six months was undertaken at three sites (1yr-3yr- Post remediated sites, control) each measured at $30 \mathrm{~m} \times 30 \mathrm{~m}$ divided into four sub-plots in a split plot Design. Composite soil sampling was done each month at $5 \mathrm{~cm}$ depth from each study site and taken to the laboratory for nutrient analysis including, total organic carbon, total organic matter, nitrogen, phosphorus, potassium and total hydrocarbon concentration. Results showed that total hydrocarbon concentration was $1.4038 \mathrm{mg} / \mathrm{kg}$ (control), $237.3 \mathrm{mg} / \mathrm{kg}$ (lyr-remediated) and $120.119 \mathrm{mg} / \mathrm{kg}$ (3yr post remediated sites). Percentage total nitrogen was $6.826 \%$ (control), 5.386\% (lyr-post remediated) and $5.985 \% \mathrm{mg} / \mathrm{kg}$ (3yr-post remediated). Total phosphorus and potassium was $15.408 \mathrm{mg} / \mathrm{kg}$ and $7.516 \mathrm{mg} / \mathrm{kg}$ (control), $14.078 \mathrm{mg} / \mathrm{kg}$ and $8.626 \mathrm{mg} / \mathrm{kg}$ (1yr-post remediated sites) and $16.403 \mathrm{mg} / \mathrm{kg}$ and $7.912 \mathrm{mg} / \mathrm{kg}$ (3yr post remediated sites). The control sites recorded a concentration of $26.36 \%$ total organic carbon, and $45.45 \%$ total organic matter. At 1 yr post remediated sites, it was $49.18 \%$ total organic carbon, $84.79 \%$ total organic matter. In 3 yrs post remediated sites, total percentage organic carbon was $38.86 \%$ and total organic matter was $67.01 \%$. Abundance of soil microarthropods was recorded as 375 (control), 88 (1yr post remediated) and 162 (3yr- post remediated) sites. Tillage remediation indicated that the ecosystem is returning at a very slow rate, as there was a slight decrease in organic nutrients from the control to the remediated sites.
\end{abstract}

Keywords: Organic matter, organic nutrients, remediated sites, soil nutrients, soil microarthropods, total hydrocarbon concentration.

\section{INTRODUCTION}

Hydrocarbon contaminated soil ecosystem is an ecosystem which has been polluted by crude oil spills, leakages from pipelines. Oil spills involve the release of dangerous hydrocarbons such as benzene and Polycyclic Aromatic Hydrocarbons (PAHs) into the environment, including the soil (Legborsi,

*Corresponding author

E-mail: gtambeke $a$ yahoo.com;

Tel: +2348037048057
2007). In this soil ecosystem, the availability of nutrients and its distribution which is usually controlled by fossorial arthropods including soil microarthropods is altered. Soil microarthropods are fossorial arthropods generally less than $2 \mathrm{~mm}$ in sizes, which except with some level of magnification (Badejo, 1998, Chinelo et al., 2014) do not permit an in depth study of their morphological features with the naked eye (Kapp et al., 2013). They live along with other fossorial arthropods whose detail morphological features 
can be studied without magnification at soil surfaces, interphases, and top soil, feeding on decaying vegetation, bacteria, fungi, protists and nematodes (Holowko, 2010), where they are often subjected to chemical deterioration from hydrocarbon contamination caused by crude oil spills, and leakages of pipelines. A total of 3,291 spills had occurred within 2007 and 2012 with an average of 549 per year in the Niger Delta (Ikarama inclusive) (NOSDRA, 2015). Some effects of such contamination included death of soil fauna due to asphyxiation (Osuji and Onojake, 2006), decrease in the abundance and changes in vertical migration of soil microarthopods (Gbarakoro et al., 2011). In an attempt to reverse the alteration, some remediation measures are adopted, and notable among them is the application of tillage remediating agent.

Tillage is a conventional process usually employed to accelerate recovery of contaminated ecosystem (Oyedeji, 2016). Remediation is a much safer and less expensive process that is increasingly gaining value in treating contaminated soil returning them to their predisturbance level (Pereira and Alves, 2012). The most common type of remediating process is the in-situ form and it is used worldwide (Wuana and Okiamen, 2011). Tillage is a cleanup approach usually conducted at the site (in-situ) of pollution such that the pollutant can be removed without disturbing the environment.

Remediation adopted a positive result in studies carried out by Imasuen et al., (2014) in Koko and Ajoke communities, Niger Delta, Nigeria, which drastically reduced total Nitrogen and Phosphorous. This was accredited to the remediating agent and indicates that the remediation process used had no restoration effect on soil parameters as the remediating agent consumes it in remediation process. According to Tanee and Albert (2011), nutrients of both the remediated site and un-remediated site as regarding nitrates and phosphate did not show appreciable differences, hence the process of remediation was effective. Reduction of nutrients in the soil may be attributed to microbial degradation which enabled the utilization of available nutrients for their metabolic activities (Das and Chandram,
2010). Also the THC value of the remediated site as compared to the polluted and control sites reduced due to the remediation process whereby microorganisms utilized the hydrocarbon as energy source for their metabolic activities (Tanee and Albert, 2011, Adams et al., 2015). A similar occurrence was also noted by Ayotamuno et al., (2006) where results showed a noticeable reduction in percentage THC and organic content of the soil in the remediated sites. The form of remediation (applied fertilizer and tillage) increased hydrocarbon degradation.

Tillage (in-situ) was the remediation process used by Shell Nig. Ltd. in the remediation of contaminated sites at Ikarama community. Remediation from available literature has been known to: (i) reduce soil nutrients when the process is on-going, (ii) be effective as no appreciable difference in nutrients was observed between remediated and unremediated sites, (iii) reduce $\mathrm{THC}$ values in the remediated sites, by increasing its degradation where a combination of fertilizers and tillage was the remediating agent. Furthermore, since the fossorial arthropods have the capacity to control nutrient availability for and perhaps uptake by plants (Schowalter, 2011), the present study was undertaken with the following objectives;

(i) To assess the impact of tillage remediating agent on soil nutrients in hydrocarbon contamination soil ecosystem.

(ii) To evaluate the relationship between available soil nutrients and abundance of soil microarthropods in a tillage remediating hydrocarbon-contaminated soil.

\section{MATERIALSAND METHODS}

\section{Study Area}

The study was conducted at Ikarama community, Yenagoa Local Government Area, Bayelsa State, Nigeria. Three sites; the remediated sites which were one year post remediated site (Site A) called "12" Adibawa-Okordia Manifold right of way (5'09' 19.851" N and 6"27'06.882") and a three year post remediated site (Site B) named "14" Okordia-Rumuekpe Pipeline ( $5^{\circ} 08^{\prime} 05.7228^{\prime \prime} \mathrm{N}$ 


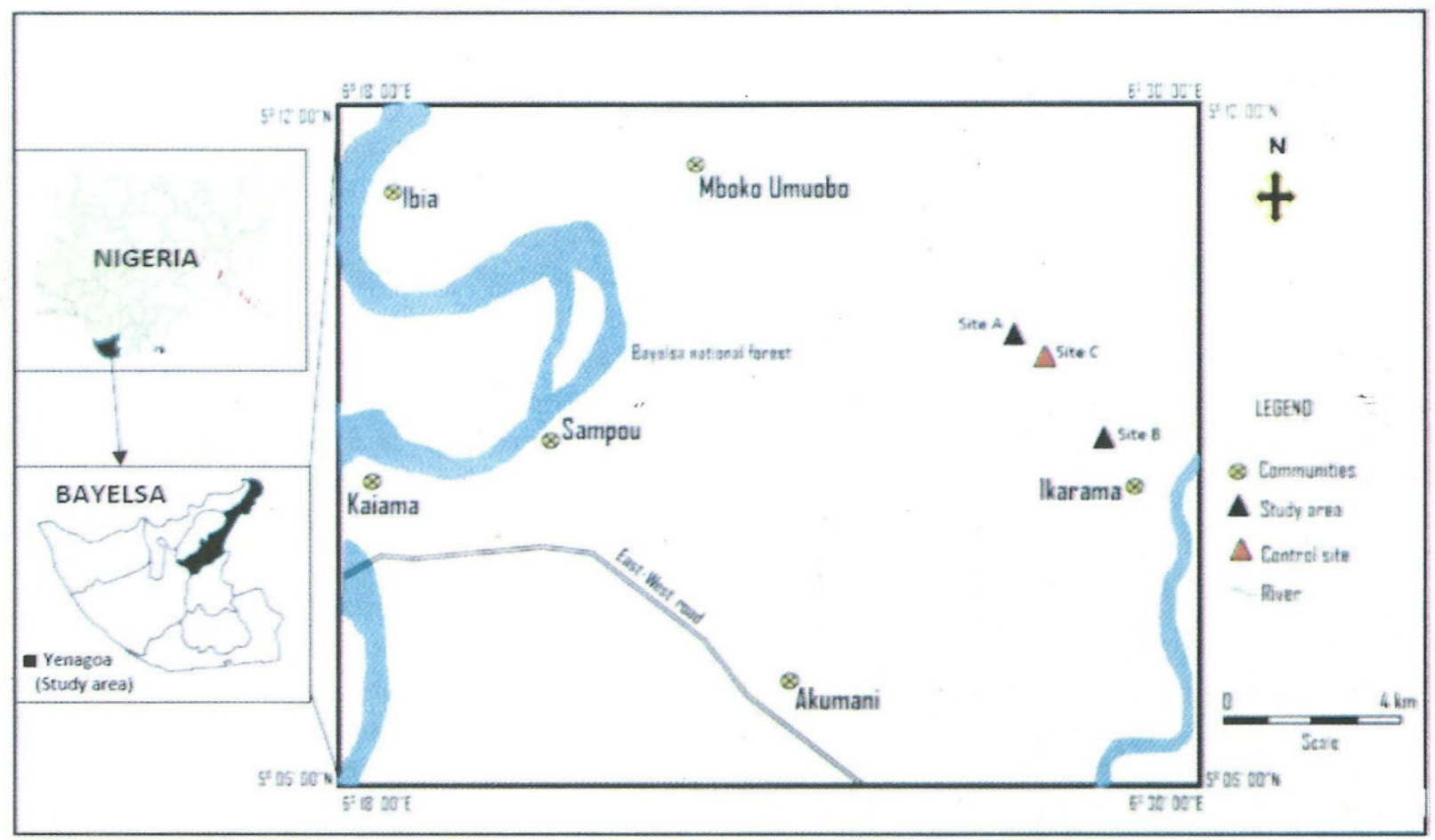

Figure 1: Map of study sites in Yenagoa L.G.A, Bayelsa State

was a farm bush $\left(5^{\circ} 08^{\prime} 59.082^{\prime \prime} \mathrm{N}\right.$ and $6^{\circ} 27^{\prime}$ 21.8448"E) (Figure 1). Sites A and B are owned by Shell Petroleum Development Company, and information about type of tillage remediation and age of remediation activities were obtained from the Department of Oil Pollution Control, Ministry of Environment, Bayelsa State. Accordingly, oil spills caused by

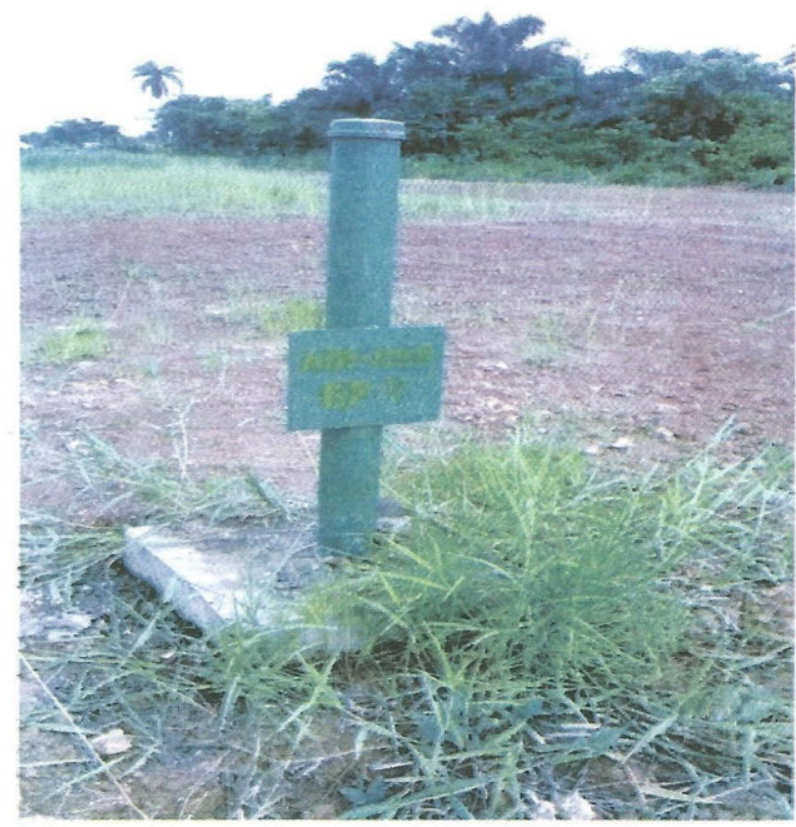

Plate 1: Site A (1 year post-remediated site) pipeline leakages occurred at Ikarama study sites in 2009 and was remediated in 2012 and 2014 at B and Asites respectively.

The type of remediation used at the study sites was entirely tillage system, where the contaminated indigenous soil was dug to about $5 \mathrm{~cm}$ depth and thoroughly mixed. This system enhanced the mixing of the surface soil with the lower depth soil so as to dry out the impacted oil through exposure to air, and sunlight. The impacted site was elevated in such a manner that the oil from the soil drained into a small drainage dug at the side of the elevated soil to allow passage of oil to one direction for recovery. This system further increases the rate of degradation activities of the indigenous microorganism in the impacted sites, particularly as it loosened the soil pores for faster movement of the organisms.

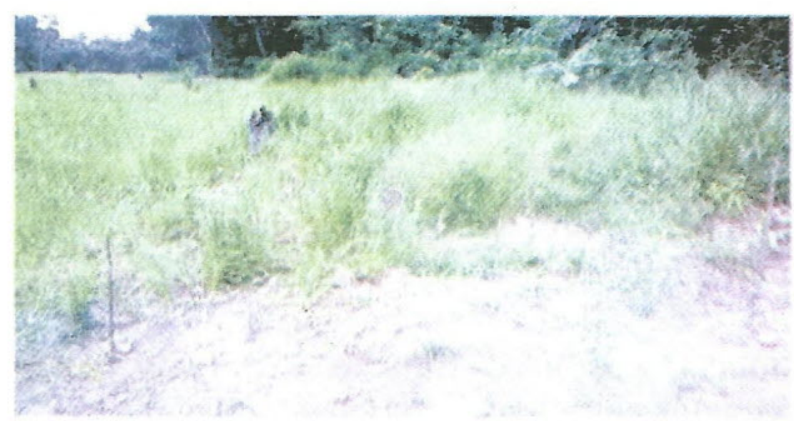

Plate 2: Site B (3 years post-remediated site) 


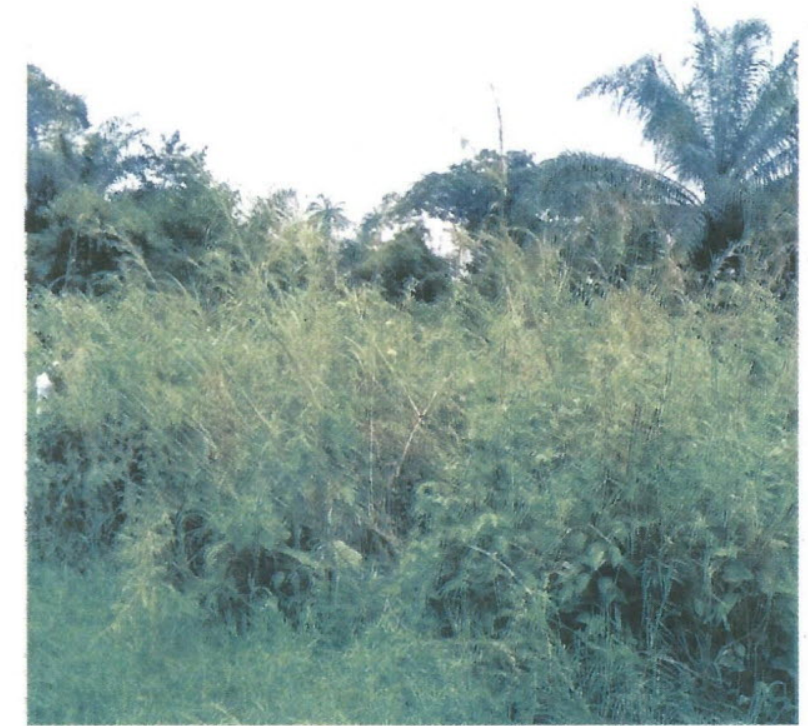

Plate 3: Site C (Control/ Unpolluted Site)

\section{Study Design/Sampling}

Each site measured at $30 \mathrm{~m} \times 30 \mathrm{~m}$ was divided into four sub-plots representing four replicates. Each replicate was $1 \mathrm{~m}$ apart. Soil samples were collected randomly, once in every month for six months (June to November, 2015), using an $8.5 \mathrm{~cm}^{2}$ diameter bucket-type auger whose height of the bucket is $35 \mathrm{~cm}$ from $0-20 \mathrm{~cm}$ depth. The samples were taken to the Entomology Research Laboratory, Department of Animal and Environment Biology, University of Port Harcourt for extraction of fossorial arthropods, particularly soil microarthropods.

Composite soil sampling was done each month at $5 \mathrm{~cm}$ depth from each study site. Samples were thoroughly mixed and put in an appropriately labelled black polyethene bag which was taken to the Laboratory for Nutrient analysis: Total Organic Carbon (TOC), Total Organic Matter (TOM), Nitrogen, Phosphorus, Potassium and Total Hydrocarbon Content (THC).

\section{Soil Microarthropods Extraction and Identification}

Modified Bukard Model of Berlesse-Tullgren funnels was used for the extraction. The extractor complex was enclosed in a metallic cabinet and it consisted of two 7-unit rows (14 units). Each extracting unit consists of a metal container with a fitted $2 \mathrm{~mm}$-mesh wire guaze at the base, a metallic funnel, and a $60 \mathrm{~W}$ electric bulb above each funnel, shaded with a metal cone. The bulbs in each unit were connected to an electric source.

Extraction was done by placing the collected soil samples in the metal containers of the extracting units, labelled according to the inscription on the plastic bags with which the soil samples were collected. The metal containers were then placed above the metal funnel that opens into a labeled collecting plastic vial containing $70 \%$ ethanol for smooth collection and preservation. The electric source was switched on to light up the bulbs. Extraction commenced once the light bulbs were on as the bulbs served as a heat source, creating a temperature and humidity gradients in the soil samples. This forced active soil fauna to migrate downward and eventually fall into the collecting vials below (Andrea, 2007). Extraction lasted for seven days, followed by sorting and identification.

Identification was carried out by the use of identification keys (Krantz, 1978; Norton, 1990), pictures of past works, and those on the internet. Where necessary, compound microscope were used to aid identification.

The abundance of the identified fossorial arthropods (both less or more than $2 \mathrm{~mm}$ size) were used to evaluate relationship of species with available nutrients.

\section{Determination of Soil Available Nutrients}

Composite soil samples were air dried at room temperature in the laboratory and then kept for organic nutrient analyses (except potassium). Some of the samples were oven-dried at $100^{\circ} \mathrm{C}$ for $24 \mathrm{hrs}$, after being wrapped in aluminum foil, and then ground in a mortar and sieved through a $2 \mathrm{~mm}$ mesh size sieve. The fine particles were afterwards digested and used to analyse potassium concentration in the sample.

\section{Total Organic Carbon in Soil}

$0.5 \mathrm{~g}$ of air-dried homogenized and sieved soil sample was put in a conical refluxing flask. $10 \mathrm{ml}$ of standard potassium dichromate solution was added and swirl to mix, $15 \mathrm{ml}$ of concentrated $\mathrm{H}_{2} \mathrm{SO}_{4}$ was carefully added. The flask was connected to the condenser and 
cooling water was turned on. The open end of the condenser was covered with a small beaker and the conical flask was placed on a hot plate and refluxed for one hour. The condenser was allowed to cool and rinsed down with distilled water into the conical flask. $100 \mathrm{ml}$ of distilled water was added after the flask was disconnected from the condenser. The flask was gently mixed by swirling and five drops of ferroine indicator was added. This was titrated with ferrous ammonium sulfate to the end point, where colour change from bluegreen to violet red was observed. Both initial and final reading was recorded and organic carbon analysed to determine if the level of carbon in the soil is excess or low. In the same way, the blank sample was prepared but without the soil sample.

Organic carbon $(\mathrm{mg} / \mathrm{g})$ calculated using the formula:

Organic Carbon $(\mathrm{mg} / \mathrm{g})=$

$\left(18 \times C \times \frac{v}{M}\right) \times\left(1-\frac{V_{2}}{V_{z}}\right)$

Where: $\mathrm{C}=$ Concentration in $\mathrm{Mol}^{-1}$ of the dichromate solution $(0.166 \mathrm{M})$

$\mathrm{V}=$ Volume of dichromate solution used $(10 \mathrm{ml})$

$\mathrm{V}_{1}=\quad$ Volume of titrant used $(\mathrm{ml})$

$\mathrm{V}_{2}=$ Volume of titrant used up in the blank (ml)

$\mathrm{M}=$ Weight of Sample used $(\mathrm{g})$ Total Organic Matter (TOM), was calculated by

multiplying

organic carbon by

percentage

1.724 .

\section{Nitrate-Nitrogen in Soil}

$10 \mathrm{ml}$ of sample (extracted from the soil sample) or aliquot made up of $10 \mathrm{ml}$ (containing between $0.1-1 \mathrm{mg} \mathrm{NO}_{3}-\mathrm{N}$ ) was transferred with distilled water into a boiling tube. The boiling tube was put into a cool water bath and added with $2 \mathrm{ml} 30 \% \mathrm{NaCl}$ solution. The mixture was swirled thoroughly and $10 \mathrm{ml} \mathrm{H}_{2} \mathrm{SO}_{4}$ solution was added. Mixture was swirled again, allowed to cool and $5 \mathrm{ml}$ brucine sulphalic acid added. The tube was swirled to mix thoroughly and placed in a well stirred boiling water bath maintained at $95^{\circ} \mathrm{C}$. After 20 minutes, the sample was removed and immersed in a cool water bath and allowed to cool to room temperature. Absorbance was measured at $470 \mathrm{~nm}$ using distilled water treated in the same manner as blank. A standard curve was plotted using nitrate standard solution treated in the same manner as the sample.

$\mathrm{Mg} / \mathrm{NO}_{3}-=\mathrm{mg} / \mathrm{LNO}_{3}-\mathrm{Nx} 4.43$

\section{Phosphorus in Soil samples}

$35 \mathrm{ml}$ (extracted from the soil sample) or an aliquot containing between 0.05 to $1.0 \mathrm{mg}$ phosphorus was placed in a $50 \mathrm{ml}$ volumetric flask.

Excessive colour in sample was removed by shaking about $50 \mathrm{ml}$ with $200 \mathrm{mg}$ activated carbon in an Erlenmeyer flask for 5 minutes and filter to remove carbon. Each batch of carbon was checked for phosphate. $10 \mathrm{ml}$ Vanadatemolybdate reagent was added and diluted to the mark with distilled water. A blank was prepared in which $35 \mathrm{ml}$ distilled water was substituted for the sample and treated in same manner as sample. After 10minutes, absorbance of the sample was measured against the blank at a wave length of $470 \mathrm{~nm}$. A set of serially diluted standard solutions was prepared containing 2.0, $4.0,6.0,8.0,10.0,12.0$ and $16.0 \mathrm{ml}$ in $50 \mathrm{ml}$ final volume, corresponding to $0.10,0.20,0.30$, $0.40,0.50,0.60$ and $0.80 \mathrm{mg} \mathrm{Po}_{4}{ }_{4}-\mathrm{p}$ respectively, the standards were treated in the same manner as the samples and the absorbance measured against a blank. A curve is plot of absorbance against concentration.

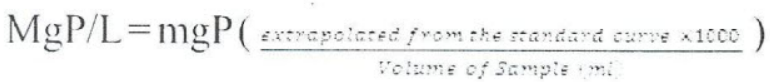

\section{Potassium in Soil Sample}

Potassium in the soil sample was determined by firstly digesting the samples. Samples collected from the three sites were digested for each month for six months. Three empty $250 \mathrm{ml}$ beaker was weighed and recorded. Afterwards, $3 \mathrm{~g}$ of each soil samples was poured into each beaker which was reweighed and recorded. Beakers, Nitric acid $\left(\mathrm{HNO}_{3}\right)$ and Hydrochloric acid $(\mathrm{HCl})$ were placed in the fume cupboard powered by an 
electric source. $10 \mathrm{ml}$ of $\mathrm{HCl}$ and $30 \mathrm{ml}$ of $\mathrm{HNO}_{3}$ was poured into each beaker containing $3 g$ of sample. It was stirred and placed in an electric cooker already turned on in the fumes cupboard. The beakers were allowed to boil and frequently checked if samples were digested. Reduction of bubbles and fumes from each beaker indicated that sample was digested. Digested samples were dropped from the heat and allowed to cool. Whatman No. 42 filter papers were folded in funnels and placed in $100 \mathrm{ml}$ beakers to filter digested samples. Distilled water was added to filtered samples up to $100 \mathrm{ml}$ of beaker and mixture was turned into labelled vials. The mixture was used to determine potassium using a flame Atomic Absorption Spectrophotometer (AAS) model (Agilent 55BSPECTRAA) which was calibrated with different concentrations of the metal of interest using the resonance wavelength of the metal and an appropriate hollow Cathode Lamp.

The concentrations of the metals were calculated using the equations:

$$
\text { MetalConcentration }(\mathrm{Mg} / \mathrm{Kg})=\frac{(x-y) v_{2}}{v_{2}}
$$

Where $\mathrm{x}=$ concentration of metals obtained from atomic absorption spectrophometer for sample $(\mathrm{mg} / \mathrm{l})$ $\mathrm{y}=$ concentration of metals obtained from atomic absorption spectrophometer instrument for blank

$\mathrm{V}_{1}=\quad$ Volume of digested sent for $\mathrm{V}_{2}=\quad$ Volume sample $(\mathrm{g})$

Total Hydrocarbon Content in Soil Sample Soil samples were air dried and sieved using a $1 \mu \mathrm{m}$ sieve. $5 \mathrm{~g}$ of the weighed sampled was poured into a conical flask, $10 \mathrm{ml}$ of $\mathrm{n}$-hexane was added and the sample was extracted in a mechanical shaker. Additional $10 \mathrm{ml}$ of $\mathrm{n}$-hexane was used for complete extraction and the extract collected in a $25 \mathrm{ml}$ standard flask. This was fully make up to mark with n-hexane.

This was followed by spectrophotric measurement in which a sample curvette was filled withn-hexane as the Genesis 10 uv spectrophometer.
The transmittance was adjusted to 100 percent that is zero absorbance and the wavelength was set at $425 \mathrm{~nm}$. The absorbance of the extracted oil was taken from the gradient of the calibration curve. The total hydrocarbon content was calculated using the formula:

$\mathrm{THC}$ in $\mathrm{mg} / \mathrm{Kg}=$

Absorbanes XVolume of $n-h e x a n e \times$ Gratient $\times 1000$ Weight of sampie used

\section{Statistical Analysis}

Field and laboratory data were subjected to statistical analysis Analysis of Variance (ANOVA). Mean comparison was done using Tukey (Honestly Significant Difference) Test to assess the significant differences of soil microarthropods abundance to the level of contaminants and available nutrients among the studied sites, with level of significance setat $\mathrm{p}>0.05$.

\section{RESULTS}

Impact of Tillage Remediation on Soil Nutrients The mean value of the Total Hydrocarbon (THC) content among the study sites, showed a high concentration of $237.30 \mathrm{mg} / \mathrm{kg}$ (1yr-post remediated site), and least concentration of $1.40 \mathrm{mg} / \mathrm{kg}$ (3yr-post remediated site) (Table 1).

The concentration of nutrients; N, P, K among the study sites, indicated that total phosphorus (P) was relatively high with $16.40 \mathrm{mg} / \mathrm{kg}$ recorded at the $3 y r-p o s t$ remediated site and the least concentration of $5.39 \mathrm{mg} / \mathrm{kg}$ of total nitrogen was

Table 1: Mean values of soil chemical parameters in the three studied sites

\begin{tabular}{|c|c|c|c|}
\hline \multirow[t]{2}{*}{ PARAMETERS } & \multicolumn{3}{|c|}{ SITES } \\
\hline & $\begin{array}{c}\text { OYR } \\
\text { (Control) }\end{array}$ & $1 \mathrm{YR}$ & 3YRS \\
\hline THC (mg/kg) & 1.401 & 237.3 & 120.12 \\
\hline TN $(\%)$ & 6.83 & 5.39 & 5.99 \\
\hline $\mathrm{TP}(\mathrm{mg} / \mathrm{kg})$ & 15.41 & 14.08 & 16.40 \\
\hline TK $(\mathrm{mg} / \mathrm{kg})$ & 7.52 & 8.63 & 7.91 \\
\hline $\operatorname{TOC}(\%)$ & 26.36 & 49.18 & 38.86 \\
\hline ТОМ $(\%)$ & 45.46 & 84.79 & 67.01 \\
\hline
\end{tabular}

Legend: $\mathbf{T H C}=$ Total Hydrocarbon Content. $\mathrm{TN}=$ Total Nitrogen, $\mathrm{TP}=$ Total Phosphorus, $\mathbf{T K}=$ Total Potassium. TOC $=$ Total Organic Carbon, $\mathbf{T O M}=$ Total Organic Matter, $0 \mathbf{Y} \mathbf{R}=$ Unpolluted $/$ control site,

$1 \mathrm{YR}=1$ year post-remediated site, 3YRS $=3$ years post-remediated site 
recorded at the lyr-post remediated sites (Table 1). The results also indicated that total organic carbon and total organic matter were relatively high at 1yr-and 3yr-post remediated sites, and the least concentration occurred at the control site (Table 1).

\section{Abundance of Soil Microarthropods in Tillage Remediated Sites}

Total abundance of soil microarthropods collected from the three studied sites at the end of the period of study was recorded. A total of 625 individuals of soil micro arthropods were collected consisting of 375 recorded in the control, 88 and 162 in the $1 \mathrm{yr}-$ and 3 yr post remediated sites, respectively (Table 2 ).

Table 2: Species abundance of soil microarthropods at different months of collection

\begin{tabular}{lcccc}
\hline & \multicolumn{4}{c}{ Sites } \\
\cline { 2 - 5 } Sampling & $\mathbf{0}$ & $\mathbf{1}$ & $\mathbf{3}$ & \\
Periods & Year & Year & Years & Total \\
June & 96 & 26 & 37 & 159 \\
July & 79 & 18 & 65 & 162 \\
August & 76 & 25 & 33 & 134 \\
September & 41 & 9 & 7 & 57 \\
October & 19 & - & - & 19 \\
November & 64 & 10 & 20 & 94 \\
TOTAL & 375 & 88 & 162 & 625 \\
\hline
\end{tabular}

Legend: 0YEARS $=$ Control site $($ Site $C)$,

$1 \mathrm{YEAR}=1$ year post-remediated site (Site A), 3YEARS $=3$ years post-remediated site (Site B)

Cryptostigmata among the mites-soil microarthropod orders was the most abundant group with a total of 263 individual species representing $(42.08 \%)$ of the overall total of 625 soil microarthropods, and the least abundant was prostigmata with one species representing $0.16 \%$ (Table 3). Among other fosorial arthropods, psocoptera was the most abundant with 122 individual species, representing $19.52 \%$ and symphyla being the least with 3 individuals representing $0.48 \%$ (Table 3 ). Leposcelis bostrichophila (Order: Psocoptera), followed by Bambara sp. (Order: Coleoptera) were the two species that recorded the highest abundance of 122 and 33 individuals, respectively. The most abundant species among the mites were Mixacar us sp. and Belha sp. (both Cryptostigmata) which recorded 51 and 50 individuals, respectively (Table 3).
Table 3: Individual species and orders of microarthropod abundance

\begin{tabular}{|c|c|c|c|c|}
\hline \multirow[b]{2}{*}{ SPECIES } & \multicolumn{3}{|c|}{ Sites } & \multirow[b]{2}{*}{ Total $(\%)$} \\
\hline & $\begin{array}{c}\text { 0 Year } \\
\text { (Control) }\end{array}$ & 1 Vear & 3 Years & \\
\hline \multicolumn{5}{|l|}{ Cryptostigmata } \\
\hline Opprass. & 2 & - & 1 & 3 \\
\hline Anne'sticalus sp. & 1 & 4 & 1 & 6 \\
\hline Acheogozctes magnus & 20 & 13 & 12 & 45 \\
\hline \multicolumn{5}{|l|}{ Bicrothermania } \\
\hline nigeriana & 14 & - & - & 14 \\
\hline Belbasp. & 35 & - & 15 & 50 \\
\hline Galumna nigeriana & 34 & 1 & 4 & 39 \\
\hline Vothrus incavanus & 5 & 1 & - & 6 \\
\hline Mivacarus sp. & 30 & 5 & 16 & 51 \\
\hline \multicolumn{5}{|l|}{ Scheloribates } \\
\hline rorubaensis & 20 & 5 & 6 & 31 \\
\hline Cephalidsp. & 4 & 1 & - & 5 \\
\hline Vothure infecansis & 1 & 3 & - & 4 \\
\hline \multicolumn{5}{|l|}{ Parallonothuzis } \\
\hline nigeriensis & 2 & 2 & 1 & 5 \\
\hline Atropocarus nigeriensis & 3 & - & - & 3 \\
\hline Mesoplophora ifeana & 1 & - & - & 1 \\
\hline Sub Total & 172 & 35 & 56 & $263(42.08 \%)$ \\
\hline \multicolumn{5}{|l|}{ Mesostigmata } \\
\hline Macrochelidsp. & 14 & 4 & 10 & 28 \\
\hline Parasitidsp. & 15 & 5 & 11 & 31 \\
\hline Tiachliuropoda sp. & 6 & - & - & 6 \\
\hline Rhodacarus sp. & 32 & 1 & 6 & 39 \\
\hline Uropodasp. & 6 & - & - & 6 \\
\hline Polyaspidsp. & 17 & 1 & 4 & 22 \\
\hline Prodinichus sp. & 1 & - & - & 1 \\
\hline Gamisina sp. & - & - & 2 & 2 \\
\hline Iphidinychus sp. & 1 & - & - & 1 \\
\hline Sub Total & 92 & 11 & 33 & $136(21.76)$ \\
\hline \multicolumn{5}{|l|}{ Prostigmata } \\
\hline Bdellidae sp. & - & - & 1 & 1 \\
\hline Sub Total & - & - & 1 & $1(0.16)$ \\
\hline Paronella sp. & 1 & & - & 1 \\
\hline Hypogastura brevis & 1 & & - & - \\
\hline Isotomorus palustris & 16 & & - & 2 \\
\hline Cryptophagussp. & 7 & & 5 & 1 \\
\hline Folsomia candida & - & & - & 1 \\
\hline \multicolumn{5}{|l|}{ Tomocerus } \\
\hline lamelliferous & 4 & & - & - \\
\hline Lepidocrytus orientalis & 1 & & - & - \\
\hline Dicrytomma marmorata & 1 & & 1 & - \\
\hline Siminthurinus niger & 1 & & - & - \\
\hline Entomobryasp. & 1 & & - & - \\
\hline Sub Total & 33 & & 6 & 5 \\
\hline \multicolumn{5}{|l|}{ Psocoptera } \\
\hline Liposcilis bostrichophila & 43 & & 31 & 48 \\
\hline Sub Total & 43 & & 31 & 48 \\
\hline \multicolumn{5}{|l|}{ Coleoptera } \\
\hline Clivina fossor & 3 & & - & . 2 \\
\hline Bamharasp. & 13 & & 5 & 15 \\
\hline Suh Total & 16 & & 5 & 17 \\
\hline \multicolumn{5}{|l|}{ Isopoda } \\
\hline (Hiscus ascllus & 4 & & - & 2 \\
\hline Sub Total & 4 & & - & 2 \\
\hline \multicolumn{5}{|l|}{ Diplura } \\
\hline Japreidsy & 12 & & - & - \\
\hline Sub Total & 12 & & - & - \\
\hline \multicolumn{5}{|l|}{ Sỵmphỵla } \\
\hline 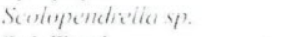 & 3 & & - & - \\
\hline Sub Total & 3 & & - & - \\
\hline Grand Total & 375 & & 88 & 162 \\
\hline
\end{tabular}

Legend: 0YEAR= Control site $($ Site $C)$.

1YEAR $=1$ vear post-remediated site (Site $A$ ).

3YEARS 3 years post-remediated site (Site B). 


\section{DISCUSSION}

The present study has shown that remediation caused by tillage processes is on-going at the post-remediated sites, as observed from three perspectives; (1) reduction in the total hydrocarbon content values, (2) variation in the availability of nutrients caused by low abundance of soil microarthropods, including other fossorial arthropods, and (3) near equality of nutrients concentration at the control and three year postremediated sites.

Okiwelu et al., (2011), noted that hydrocarbon concentration caused a reduction in species abundance, and this was also observed in this present study, though in this case, it is postremediated sites not unremediated sites where Okiwelu et al., (2011) studied, indicating that reduction in species abundance also occur at ongoing remediation processes in tillage postremediation sites. This observation is corroborated with the high concentration of traces of hydrocarbon which still abound at the postremediated sites, and most importantly as it exceeds the permissible concentration of THC which is $10 \mathrm{mg} / \mathrm{kg}$ (EGASPIN, 2002). Though the THC values were high, and caused low number of individual arthropod species, a reduction in percentage concentration was also recorded particularly from the $1 \mathrm{yr}$ - to $3 \mathrm{yr}$-post remediated sites, indicating an on-going remediation. This may have led Ayotamuno et al., (2006) to report that a marked decrease in THC percentage occurred among remediated sites. Statistical analysis also led credence to this observation in this present study as the mean difference was significant at the 0.05 level $(\mathrm{F}=11.76: \mathrm{P}=0.01)$, between THC levels of the control and that of the post-remediated sites.

The low abundance of soil microarthropods and its activities in corroboration with the activities of other soil fauna are responsible for the variation of soil nutrients recorded at the post-remediated sites in this study. There was a slight decrease in organic nutrients from the control to the post-remediated sites, with total nitrogen higher at the 3yr-post remediated site, and total organic matter higher at lyr-post remediated site. This observation creates a relationship of soil nutrients with soil microarthropod abundance, that the higher the relative abundance of soil microarthropods in an on-going tillage remediation site, the higher the concentration of total nitrogen, and the lower the concentrations of total organic matter and total hydrocarbon. This agrees with the positions of Imasuen et al., (2014) and Abioye et al., (2009) that remediation process consumes percentage organic matter in soil while remediating as a result of actions of microorganisms, which in this present study include the activities of soil microarthopods. Soil microarthropods have been known to activate the activities of soil microorganisms (Badejo et al., 2004; Culliney, 2013) and contribute to the distribution of soil nutrients, therefore, a reduction in their abundance will cause a reduction in distribution of soil nutrients. This is the situation in this present study, with the concentration of total phosphorus and potassium in both the control and 3yr-post remediated sites nearly equal, indicating that remediation is ongoing. The implications of these are in line with Schowalter (2011) that fossorial arthropods (microarthropods inclusive) have the capacity to control nutrients availability for and perhaps uptake by plants.

\section{CONCLUSION}

The present study has indicated the relationship between soil microarthropod's abundance and availability as well as distribution of nutrients in a post-remediated tillage enhanced remediation from crude oil soil contamination. The relationship was more at the 3yr-post remediation sites. Also, this study has shown that the application of tillage remediation, reduces total hydrocarbon and total organic matter concentration with increase in soil microarthropods with time, indicating that the remediating process is on-going with much consumption of organic matter. The study indicates that the use of tillage remediation will require longer time of recovery from crude oil contamination, thus further studies on the effect of a combination of tillage and other artificial remediation should be conducted. 


\section{REFERENCES}

Abioye, O. P., Alonge, O. A., and Ijah, U. J. J. (2009). Biodegradation of crude oil in soil amended with Melon Shell. AU J.T. 13(1): 34-38.

Adams, G. O., Fufeyin, P. T., Okoro, S. E., and Ehinomen, I. (2015). Bioremediation, biostimulation and bioaugmention: a review. International Journal of Environmental Bioremediation \& Biodegradation, 3(1): 2839.

Andrea, D. D. (2007). The effects of harvesting and decaying $\operatorname{logs}$ on Oribatid (Acari: Oribatida) Mite assemblages in Eastern Canadian mixed wood boreal forest. M.Sc Thesis, Mc Gill University, Montreal Canada.

Ayotamuno M. J., Kogbara R. B., Ogaji S. O. T., and Probert S. D. (2006). Bioremediation of a crude oil polluted agricultural soil at Port Harcourt, Nigeria. AppliedEnergy, 83(11): 1249-1257.

Badejo, M.A. (1998). Quick notes on soil microarthropod studies. Department of Zoology, Obafemi Awolowo University, IleIfe, Nigeria.

Badejo, M.A., Tian, G., and Okoh, I.O. (2004). Litter transformers as ecosystem engineers in sustainable agro ecosystems, 2:89-106.

Chilinho, S., Domene, X., Andres, P., Natal-daLuz, T., Norte, C., Rufino, C., and Duarte, A.C. (2014). Soil microarthropod community testing: A new approach to increase the ecological relevance of effect data for pesticide risk assessment. Applied Soil Ecologl; 83:200-209.

Culliney, T.W. (2013). Role of arthropods in maintaining soil fertility. Agriculture, 3(4):629-659.

Das, N., and Chandran, P. (2010). Microbial degradation of petroleum hydrocarbon contaminants: an overview. Biotechnolog! Research International, 2011:1-14.

EGASPIN (2002). Environmental Guidelines and Standards for the Petroleum Industry in Nigeria. Published by Directorate of Petroleum Resources (DPR) Nigeria, and Global Legal Group Limited, London, UK.
Gbarakoro, T.N., Okiwelu, S.N., Badejo, M.A., and Umeozor, O.C. (2011). Soil Microarthropods in a Secondary Rainforest, Rivers State, Nigeria - III- Partial Recovery after an oil spill. International Journal of Ecosistem, 2(2): 1-4.

Holowko, P. (2010). Berlese funnel. Invertebrate biodiversity in the soil. Juniata College. www.juniata.edu/services/science

Imasuen, O. I., Galasi, D. F., and Omorogeria, O. M. (2014). Impact assessment and bioremediation of oil contaminated soil. A case study of Koko and Ajoke communities, Niger Delta, Nigeria. J. Appl. Sci. Environ. Manage, 18(1):55-60.

Kapp, C., Storey, S.G., and Malan, A.P. (2013). Options for health measurement in vineyards and deciduous fruit orchards, with special reference to Nematodes.

Krantz, G. W. (1978). A Manual of Acarology. Oregon 173 State University Book Stores Inc. Corvallis.599pp.

Legborsi, S. P. (2007). The adverse impact of oil pollution on the environment and well-being of a local indigenous community: The experience of the Ogoni people of Nigeria. A paper presentation under the United Nations Department of Economic and Social Affairs, Division for Social Policy and Development.

Norton, R. A. (1990). Acarina: Oribatida. In: Dindal, D. L. (Ed.), Soil Biology Guide. John Wiley, New York, 779-803.

NOSDRA (2015). National Oil Spill Detection and Response Agency In: Robert Cui, (Ed). Oil Multinationals in Nigeria: Human Rights, Sustainable Development and the Law. Anchor Academic Publishing, Germany, 50pp.

Okiwelu, S.N., Gbarakoro T.N., and Badejo, M.A. (2011). Soil microarthropods in a secondary rainforest, Rivers State, NigeriaII-Ecosystem Health Indicators of oil pollution. Journal of Ecologr and Natural Environment, 3(1):29-32.

Osuji, L.C., and Onojake, C.M. (2006). Field reconnaissance and estimation of petroleum hydrocarbon and heavy metal content of soil affected by the Ebocha- 8 oil spillage in Niger Delta, Nigeria. Journal of Environmental 
Management,79(2) 133-139.

Oyedeji, A. A. (2016). Impacts of selected leguminous tree species and kaolinite preamendment on (Doctoral dissertation). A Thesis submitted in partial fulfilment of the requirements of the University of Wolverhampton for the degree of doctor of Philosophy.

Pereira, L., and Alves, M. (2012). Dyes environmental impact and remediation. In Environmental protection strategies for sustainabledevelopment, Springer Netherlands, pp. 111-162.

Schowalter, T.D. (2011) Insect Ecology. An
Ecosystem Approach, $3^{\text {td }}$ edition, Elsevier Inc. U.K. 633 pp.

Tanee, F. B. G., and Albert, E. (2011). Biostimulation potential of sawdust on soil parameters and cassava (Manihotesculenta; Grantz) yield in crude oil polluted tropical soil. Advances in Environmental Biolog!: 5: 938-945.

Wuana, R. A., and Okieimen, F. E. (2011). Heavy metals in contaminated soils: a review of sources, chemistry, risks and best available strategies for remediation. Isrn Ecology, 2011.1-21.

*Gbarakoro, T. N., Ogele, E. J. and Umeozor, O. C.

Nigerian Jounal of Entomology.

Published by the Entomological Society of Nigeria

www.esn.org.ng

ISSN: 0331-0094

Volume 33, 2017

pp 111-120

DOI:10.36108/NJE/7102/33(0131) 